P-ISSN: 2615-1723

E-ISSN: 2615-1766

Oktober 2019
Jurnal Riset Pendidikan Dasar

02 (2), (2019) 94-101

Submitted: Juli, Accepted Agustus, Published: Oktober

\title{
Peningkatan Kerjasama Belajar Melalui Model Test-Taking Teams Berbantu Multimedia Powerpoint Tema 8 di Sekolah Dasar
}

\author{
Rahma Nur Izza \\ Pendidikan Guru Sekolah Dasar, Universitas Muhammadiyah Purwokerto, Indonesia \\ *Korespondensi. E-mail: Rahmanurizza22@gmail.com
}

\begin{abstract}
Abstrak
Penelitian ini bertujuan untuk meningkatkan sikap kerjasama peserta didik pada Tema 8 "Daerah Tempat Tinggalku" di Kelas IV SDN 02 Bumiayu dengan menggunakan pembelajaran kolaboratif teknik TestTaking Teams berbantuan multimedia powerpoint. Jenis penelitian ini adalah Penelitian Tindakan Kelas yang terdiri dari dua siklus dan setiap siklus terdiri dari 2 kali pertemuan. Obyek penelitian ini yaitu peserta didik kelas IV yang berjumlah 36 peserta didik yang terdiri dari 23 peserta didik laki-laki dan 13 peserta didik perempuan. Instrumen yang digunakan dalam pengumpulan data meliputi instrumen tes dan non-tes. Hasil observasi pada proses pembelajaran siklus I dan siklus II menunjukkan bahwa sikap kerjasama peserta didik mengalami peningkatan, pada sikap kerjasama peserta didik siklus I memperoleh nilai persentase sebesar $62,1 \%$ menjadi $93,05 \%$ di akhir siklus II dengan kriteria sangat baik. Persentase kerjasama peserta didik telah mencapai indikator keberhasilan yang telah ditentukan yaitu dengan kriteria baik dan meningkat.
\end{abstract}

Kata Kunci: Sikap Kerjasama; Pembelajaran Kolaboratif; Teknik Test-Taking Teams; Multimedia Powerpoint

\section{Improving Study in Teamwork Through Test-Taking Teams Model Assisted By Multimedia Powerpoint Theme 8 in Elementary School}

\begin{abstract}
This research aims to enhance the students teamwork in the theme 8 "Area Where I Lived" in class IV Elementary School 2 Bumiayu using collaborative learning techniques Test-Taking Teams assisted by multimedia Powerpoint. This type of research is a class action research consisting of 2 cycles and each cycle consists of 2 times meeting. The research object is class IV students which consists of 36 students consisting of 23 male learners and 13 female learners. The instruments used in data collection include test and non-test instruments. The results of the observation on cycle I and cycle II study showed that the cooperation of learners increased, in cooperation cycle I gained a percentage value of $6.21 \%$ to $93.05 \%$ at the end of cycle II with criteria Excellent. The percentage of student cooperation has reached a determined success indicator with good criteria and increases.
\end{abstract}

Keywords: Teamwork; Collaborative Learning; Test-Taking Technique; Powerpoint Multimedia 


\section{PENDAHULUAN}

Saat ini, dunia tengah memasuki era revolusi industri 4.0 yang menjadikan teknologi sebagai basis dalam kehidupan manusia. Era revolusi industri 4.0 sekarang ini berpengaruh terhadap beberapa aspek kehidupan baik di bidang ekonomi, politik, kebudayaan, seni, dan dunia pendidikan. Hadirnya era revolusi industri 4.0 membuat dunia mengalami perubahan yang sangat cepat dan kompetitif. Perkembangan pendidikan di Indonesia dapat kita lihat dari perubahan kurikulum yang ada di Indonesia. Kurikulum merupakan pedoman bagi guru untuk melaksanakan pembelajaran. Indonesia dalam penerapan kurikulum sudah beberapa kali mengalami perubahan, mulai dari kurikulum di era 90-an, KBK, KTSP serta kurikulum yang terbaru, yaitu kurikulum 2013, diharapkan tidak hanya aspek kognitif saja namun aspek keterampilan dan pengetahuan dapat seimbang.

Berdasarkan hasil wawancara dan observasi bersama guru kelas IV SDN 02 Bumiayu, dapat diketahui dalam proses pembelajaran guru masih menggunakan pembelajaran konvensional yang sebenarnya sudah baik namun dirasa sudah biasa dan kurang efektif di dalam menyampaikan materi khususnya tematik yang menuntut peserta didik untuk mendapatkan sendiri berbagai pengetahuan yang dipelajarinya dan menguhubungkan dengan pelajaran yang lain. Guru menyebutkan beberapa masalah yang di kelas IV diantaranya yaitu: pelaksanaan pembelajaran yang belum optimal seperti guru merasa dikejar materi setiap pembelajaran, sehingga waktu untuk penyampaian materi dirasa kurang, dan materi tidak tersampaikan dengan baik; peserta didik kurang memperhatikan guru pada saat menerangkan pelajaran; peserta didik hanya mengerjakan apa yang diperintahkan guru tanpa mengembangkan menjadi sesuatu yang berbeda; tanggung jawab dan kerjasama peserta didik yang kurang dibuktikan dengan ketika diberi tugas atau pekerjaan rumah harus selalu diingatkan serta sikap ingin menang sendiri tidak bisa diajak bekerjasama ketika mengerjakan tugas dalam berkelompok; kurangnya prestasi belajar peserta didik yang masih di bawah indeks keberhasilan ketuntasan belajar.

Masalah yang ditemukan di atas dapat di atasi dengan cara salah satunya adalah penerapan model pembelajaran kolaboratif dengan teknik Test-Taking Teams. Tujuan dari model pembelajaran kolaboratif untuk melatih kerjasama, membangun pribadi yang otonom dan pandai mengartikulasikan pemikirannya. Peserta didik bukan hanya belajar bekerjasama, tetapi mereka juga harus bertanggungjawab tehadap pembelajaran teman satu timnya dan juga pembelajaran diri mereka sendiri.

Hal tersebut sesuai dengan penelitian Quasi-eksperimen yang dilakukan oleh Pratiwi(2017) menunjukkan bahwa adanya perbedaan prestasi belajar keterampilan membaca bahasa Jerman di SMA Negeri 1 Grabag Magelang antara kelas yang diajar dengan menggunakan teknik Test-Taking Teams dan kelas yang diajar dengan menggunakan teknik konvensional.

Penerapan model pembelajaran yang tepat akan lebih baik jika dibantu dengan media yang tepat. Penggunaan media sangat penting dalam kegiatan belajar mengajar karena ketidakjelasan materi yang disampaikan guru serta kerumitan materi pelajaran dapat terbantu dengan adanya media. Memanfaatkan media akan memberikan gambaran pada peserta didik dengan jelas dan menyerupai dengan aslinya.

Hal tersebut sesuai dengan penelitian dan pengembangan (research and development) dan model pengembangan media ADDIE yang dilakukan oleh Maharani (2015) menyatakan bahwa multimedia pembelajaran interaktif berbasis Kurikulum 2013 terbukti dapat membantu guru sebagai alat bantu dalam memperjelas penyajian materi pelajaran sehingga dapat memotivasi peserta didik dan meningkatkan hasil belajar peserta didik, terbukti dari hasil nilai yang diperoleh peserta didik, serta multimedia pembelajaran interaktif berbasis Kurikulum 2013 dapat meningkatkan keefektifan terhadap hasil belajar peserta didik, memotivasi peserta didik, serta menciptakan interaksi langsung antara guru dengan peserta didik, sehingga pembelajaran lebih efektif, efisien dan menarik. 
Salah satunya media yang dapat digunakan dalam pembelajaran di kelas IV ini yaitu multimedia powerpoint. Multimedia powerpoint adalah alat perantara dalam menyampaikan materi kepada peserta diidk dan mempermudah dalam proses belajar mengajar. Materi yang akan disampaikan pada multimedia powerpoint dikemas dalam bentuk teks, gambar, animasi, dan video. Berdasarkan uraian tersebut di atas, peneliti dan guru wali kelas IV SD N 02 Bumiayu setuju akan mengadakan sebuah Penelitian Tindakan Kelas (PTK) dalam rangka meningkatkan kerjasamapeserta didik dengan judul "Upaya Meningkatkan Kerjasama Peserta Didik dengan Model Pembelajaran Kolaboratif Teknik Test-Taking Teams Berbantu Multimedia Powerpoint Pada Tema Daerah Tempat Tinggalku di kelas IV Sekolah Dasar"

\section{METODE}

Jenis penelitian ini adalah Penelitian Tindakan Kelas (PTK) yang dilaksanakan di SDN 02 Bumiayu, pada semester 2 Tahun Ajaran 2018/2019. Subjek penelitian peserta didik kelas IV yang berjumlah 36 peserta didik yang terdiri dari 23 peserta didik laki-laki dan 13 peserta didik perempuan. Desain penelitian tindakan kelas ini menggunakan desain penelitian dari Kemmis and Mc.Taggart. Instrumen yang digunakan dalam pengumpulan data meliputi instrumen non-tes. Instrumen non-tes terdiri dari observasi guru, observasi peserta didik, observasi sikap kerjasama, wawancara dan dokumen. Analisis data yang digunakan terdiri dari analisis data kualitatif.Data kualitatif adalah data yang tidak dapat diukur dengan angka, namun dapat dilihat perubahannya pada saat pembelajaran berlangsung, dalam penelitian ini didapat dari dokumen, hasil observasi, hasil wawancara.

\section{HASIL DAN PEMBAHASAN}

Hasil penelitian yang dilakukan membuktikan terjadinya peningkatan sikap kerjasama peserta didik melalui model pembelajaran kolaboratif teknik Test-Taking Team berbantuan multimedia powerpoint. Peningkatan kerjasama ini menghasilkan peserta didik yang dapat bekerjasama dengan baik, belajar bertanggungjawab terhadap pembelajaran teman satu timnya serta pembelajaran diri mereka sendiri. Bekerja sama akan membuat seseorang mampu melakukan lebih banyak hal dari pada bekerja sendirian. Menurut West (Nurwati, E dkk, 2012:2) menyatakan bahwa riset pada bidang aktivitas dan upaya manusia, jika dilakukan dengan adanya kerjasama secara kelompok, maka segala aktivitas akan menjadi efektis dan efisien.

Peserta didik dengan berbagai kemampuan dan pengalaman bekerja bersamasama dalam kelompok untuk meningkatkan mutu pelajaran dan mencapai tujuan belajar. Menurut Johnson (2011:164) menyatakan bahwa aktivitas kerjasama dapat meminimalisir hambatan mental akibat terbatasnya pengalaman dan cara pandang seseorang dalam mengerjakan segala sesuatu. Jadi dengan bekerjasama peserta didik akan dengan mudah menghargai orang lain, menerima pendapat orang lain, bertanggung jawab dan perduli terhadap sesama. Bekerjasama dapat menciptakan suasana persahabatan yang saling menghargai, kesabaran, dan kepercayaan. Melalui kerjasama akan meminimalisir persaingan atau kompetisi, dan menciptakan sikap toleransi serta perasaan mengasihi. Manusia memiliki dinamika hidup di masyarakat, yaitu sebagai makhluk individu dan sosial yang sepanjang hidupnya selalu berinteraksi dengan orang lain. Seseorang yang dapat bekerjasama dengan orang lain merupakan salah satu wujud dari keberhasilan interaksi dalam mencapai tujuan. Kerjasama mempunya fungsi yang sangat penting, digambarkan oleh Charles H. Cooley (Soekanto, S, 2014:66) yang meyatakan bahwa bekerjasama muncul dari sikap seseorang ketika orang itu menyadari bahwa segala kegiatan dapat saling membantu dan membuat pekerjaan menjadi cepat selesai serta memberikan manfaat yang banyak dan berguna bagi kehidupan.

Melalui penggunaan multimedia powerpoint juga dapat meningkatkan minat belajar peserta didik dalam menyerap materi pembelajaran menjadi aktif dan berkesan bagi peserta didik. Peserta didik mengikuti pelajaran dengan menyerap materi, seperti pendapat Burton (Rusman, dkk, 2013:8) yang menyatakan bahwa perubahan tingkah laku pada individu dari hasil kegiatan belajar dengan berinteraksi dengan masyarakat sekitar sehingga individu tersebut dapat bersosialisasi Copyright C2019, JRPD, ISSN 2615 - 1723 (Print), ISSN 2615 - 1766 (Online) 
dengan baik. Peningkatan kerjasama ini setiap peserta didik dapat dilihat pada gambar dilakukan melalui lembar observasi untuk 1.

\section{Nilai Presentase Kerjasama}

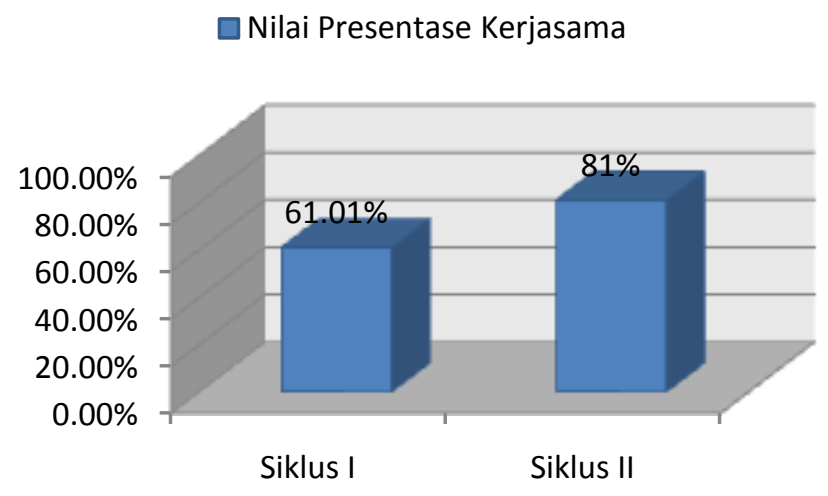

Gambar 1 Histogram Peningkatan Sikap Kerjasama Peserta Didik

Berdasarkan gambar 1 terlihat peningkatan hasil sikap kerjasama peserta didik pada setiap siklus. Peningkatan sesuai indikator keberhasilan terlihat pada siklus II yang mencapai persentase nilai presentase sebesar $81 \%$ yang sebelumnya $61,01 \%$. Tercapainya sikap kerjasama yang baik tersebut, karena ada aktivitas dan komunikasi yang baik antar peserta didik dan guru. Melalui kerjasama secara tim peserta didik yang lemah akademisnya akan terbantu dengan peserta didik yang memiliki kemampuan akademisnya lebih. Menurut Mujtahidin (2017:96) mengatakan bahwa seseorang yang memiliki karakter ini dapat dilihat dari beberapa indikator berikut:

1. Dapat bekerja secara berkelompok

2. Menghargai perbedaan pendapat

3. Suka tolong menolong

Tujuan dari kerjasama adalah untuk saling menumbuhkan sikap menghargai, tanggung jawab, peduli, kesadaran bersosial, dan keterampilan komunikasi yang baik, dengan komunikasi yang baik akan memiliki kesempatan mengungkapkan gagasan, mendengarkan pendapat orang lain, dan meningkatkan harga diri seseorang.

Hasil observasi kerjasama pada siklus I yang diperoleh peserta didik belum maksimal, kemudian pada siklus II hasil observasi kerjasama menjadi lebih baik, karena mengalami peningkatan. Peningkatan kerjasama ini dipengaruhi oleh aktivitas guru dalam melaksanakan pembelajaran.Proses kegiatan belajar mengajar yang dilakukan guru tidak terlepas dari penerapan model pembelajaran yang diterapkan, sebagai usaha untuk menyampaikan materi agar berjalan menyenangkan dan tidak membosankan. Pemilihan berbagai model, metode, strategi, pendekatan serta teknik pembelajaran merupakan suatu hal yang utama.

Pemilihan model pembelajaran yang tepat akan menjadikan proses kegiatan belajar mengajar menjadi aktif dan meningkatkan hasil prestasi belajar peserta didik. Sejalan dengan Isjoni (Sundari, H, 2015: 108) yang menyatakan bahwa penerapan model pembelajaran yang digunakan guru dalam kegiatan belajar mengajar dapat meningkatkan motivasi belajar, peserta didik dapat berpikir kritis, memiliki ketrampilan sosial serta tujuan pembelajaran tercapai, sedangkan menurut Amri (Ibrahim, 2017: 201) yang menyatakan bahwa model pembelajaran adalah suatu alat atau desain yang dapat menciptakan kondisi lingkungan yang menjadikan peserta didik dapat berinteraksi dengan individu yang lain sehingga perubahan pada peserta didik berkembang dengan baik.

Berdasarkan uraian di atas dapat disimpulkan bahwa model pembelajaran adalah rangkaian pendekatan atau stategi yang disusun oleh guru untuk mempermudah guru Copyright (C2019, JRPD, ISSN 2615 - 1723 (Print), ISSN 2615 - 1766 (Online) 
mengajar dan meningkatkan motivasi belajar peserta didik agar tujuan belajar tercapai. Metode dan teknik pembelajaran, antara keduanya sekaligus dapat berfungsi sebagai pedoman bagi guru dalam merencanakan dan melaksanakan proses kegiatan belajar mengajar di kelas.

Pada siklus I guru belum terlalu memahami model dan belum sepenuhnya terbiasa dengan model pembelajaran kolaboratif teknik Test-Taking Teams berbantuan multimedia powerpoint. Kemudian pada siklus II aktivitas yang dilakukan guru dalam pembelajaran menjadi lebih baik karena guru sudah terbiasa dan memahami model pembelajaran, dengan semakin pahamnya guru mengenai langkah-langkah pembelajaran dalam model pembelajaran kolaboratif teknik Test-Taking Teams berbantuan multimedia powerpoint, maka pemahaman peserta didik dalam menerima materi semakin baik.

Model pembelajaran kolaboratif merupakan salah satu model pembelajaran yang berpusat pada peserta didik. Melalui pembelajaran kolaboratif guru dapat mentransfer pengetahuan kepada peserta didik dengan cara membangun pemikiran mereka sendiri melalui sebuah proses asimilasi informasi ke dalam pemahaman mereka. Pembelajaran yang bermakna mampu bertahan lama melalui keterlibatan personal dan aktif. Menurut Utomo (2011:55) yang menjelaskan bahwa penerapan model pembelajaran kolaboratif dengan latar kemampuan dan pengalaman peserta didik yang disatukan bersama-sama dapat meningkatkan mutu prestasi belajar peserta didik. Sejalan dengan pendapat Chandra, R (2015:1) menyatakan bahwa pembelajaran kolaboratif yang melibatkan peserta didikdapat saling berpasangan atau kelompok kecil untuk mendiskusikan konsep, atau menemukan solusi untuk masalah. Hal ini sering terjadi dalam sesi kelas setelah peserta didik diperkenalkan dengan materi pelajaran melalui bacaan dan video sebelum kelas. Mirip dengan gagasan bahwa dua atau tiga kepala lebih baik dari satu, banyak instruktur telah menemukan bahwa melalui instruksi sebaya, peserta didik mengajar satu sama lain dengan mengatasidan mengklarifikasi kesalahpahaman.

Model kolaboratif ini lebih jauh dan mendalam dibandingkan hanya sekedar kooperatif. Istilah kolaboratif dan kooperatif memiliki arti yang hampir sama, namun ketika diaplikasikan atau diterapkan pada pembelajaran berkelompok, kedua kata ini memicu perdebatan. Menurut Barkley (2016:9) menyatakan bahwa esensi dari perbedaan antara kolaboratif dan kooperatif ialah jika tujuan pembelajaran koperatif adalah bekerja secara selaras dan saling mendukung menemukan solusi, sementara tujuan pembelajaran kolaboratif lebih memusatkan peserta didik menjadi pribadi yang otonom dan pandai mengartikulasikan pemikirannya serta mencakup keseluruhan proses pembelajaran.Hasil peningkatan aktivitas guru selama proses kegiatan belajar mengajar dalam penelitian peningkatan kerjasama peserta didik dapat dilihat pada gambar 2 .

\section{Nilai Persentase Guru}

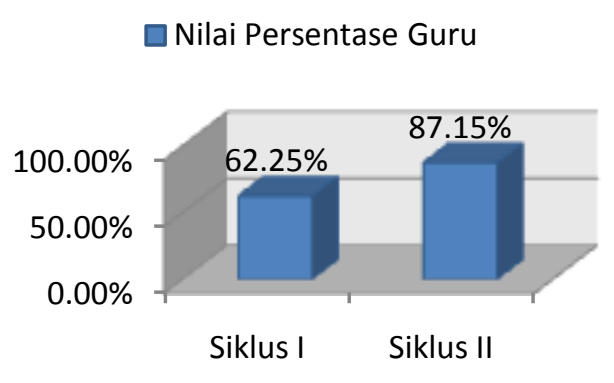

Gambar 2 Histogram peningkatan aktivitas pembelajaran guru

Berdasarkan gambar 2 di atas dapat diketahui bahwa aktivitas pembelajaran guru dalam pembelajaran kolaboratif teknik TestTaking Teams berbantuan multimedia powerpoint, dari siklus I sampai siklus II mengalami peningkatan yang cukup signifikan. Siklus I mencapai nilai presentasi $62,25 \%$ dengan kriteria baik, kemudian guru berusaha meningkatkan dan berusaha memperlajari kolaboratif teknik Test-Taking Teams berbantuan multimedia powerpoint, dengan baik, sehingga pada siklus II terjadi peningkatan aktivitas pembelajaran guru yang mencapai nilai presentasi $87,15 \%$ dengan kriteria Sangat Baik. Guru selalu berupaya memperbaiki setiap indikator yang masih kurang baik, sehingga aktivitas pembelajaran guru selalu meningkat pada setiap siklus. Peningkatan aktivitas guru dalam proses Copyright C2019, JRPD, ISSN 2615 - 1723 (Print), ISSN 2615 - 1766 (Online) 
pembelajaran sangat memperngaruhi terhadap kualitas pembelajaran sehingga sikap kerjasama peserta didik meningkat. Selaras dengan Slameto (2010:67) menyatakan bahwa menciptakan relasi atau hubungan yang baik antar peserta didik merupakan hal yang perlu dilakukan, agar dapat memberikan pengaruh yang positif terhadap belajar peserta didik. Melalui penerapan pembelajaran kolaboratif teknik Test-Taking Teams berbantuan multimedia powerpoint, guru menjadi lebih kreatif dalam mengajar dan peserta didik menjadi lebih aktif dan paham tentang materi yang berikan guru sehingga prestasi belajar peserta didik meningkat dari siklus I ke siklus II.

Guru memberi pengaruh yang besar dalam peningkatan kerjasama peserta didik, karena guru merupakan nahkoda atau yang mengatur segala aktivitas di dalam kelas yang dapat membawa situasi belajar dan menyajikan materi dengan multimedia powerpoint. Penggunaan multimedia powerpoint menunjukkan hasil yang positif, dimana multimedia powerpoint dapat menyajikan materi-materi yang ada dalam pembelajaran. Multimedia powerpoint dalam pembelajaran juga menarik peserta didik agar memperhatikan pembelajaran, sehingga semakin bertambah pula pemahaman peserta didik terhadap materi. Hal ini berpengaruh tehadap hasil sikap kerjasama yang diperoleh peserta didik. Model pembelajaran kolaboratif teknik Test-Taking Teams berbantuan multimedia powerpoint, dengan langkahlangkah pembelajaran, menurut Barkley (2016: 200) melibatkan tiga langkah diantaranya yaitu : (1) Kelompok belajar bersama untuk menghadapi ujian, (2) Mengerjakan ujian secara individual, dan (3) mengerjakan ujian secara kelompok, lalu pada akhir pembelajaran ditambahkan soal evaluasi akhir untuk mengetahui peningkatan dari penerapan model pembelajaran Test-Taking Teams berbantuan multimedia powerpoint.

Multimedia powerpoint dalam penelitian ini menjadi salah satu bahan ajar yang menarik, inovatif dan meningkatkan pengetahuan peserta didik karena materi pelajaran mudah diterima dengan baik. Perhatian peserta didik dapat difokuskan terhadap hal-hal yang dianggap penting sehingga peserta didik dapat menyerap pelajaran dengan baik. Menurut Noryanti, $\mathrm{H}$ (2014:109) yang menyatakan bahwa media powerpoint merupakan suatu alat perantara yang digunakan utnuk menjelaskan materi pelajaran yang dibuat sedemikian rupa untuk menjelaskan materi dalam sebuah program yang disajikan melalui proyektor. Selaras dengan pendapat Mason \& Hlynka (Sagar, P \& NN Pandey, 2014:77) yang menyatakanpowerpoint memiliki potensi untuk membantu peserta didik meneliti, mengatur, dan menyajikan informasi kepada rekan-rekan mereka dengan grafik yang terlihat profesional dan informasi ringkas sambil terlibat dalam pembelajaran aktif. Salah satu fitur utama powerpoint adalah menyediakan struktur untuk presentasi. Ini meningkatkan kemampuan guru untuk memesan dan mempercepat pembelajaran.

Selain adanya penggunaan media, guru juga menggunakan model pembelajaran kolaboratif teknik Test-Taking Teams berbantuan multimedia powerpoint. Model ini sangat membantu peserta didik menjadi aktif, karena mereka harus bekerjasama satu sama lain. Kegiatan pembelajaran dalam teknik TestTaking Teams melibatkan peserta didik untuk dapat saling mengajari satu sama lain dalam kelompok. Peserta didik memimpin diskusi, bersama-sama meringkas materi, mengajukan pertanyaan, dan menjelaskan materi. Teknik ini mengharuskan peserta didik bekerja dalam kelompok untuk mempersiapkan soal, tes dan membahas suatu tema atau materi. Peran pendidik hanya bertindak sebagai fasilitator. MenurutBarkley (2016: 200) mendefinisikan teknik Test-Taking Teamsmerupakan teknik yang bersifat aktifbukan pasif, mengharuskan peserta didik memberi dan menerima di saat mereka saling membantu dalam upaya memperoleh pengetahuan atau pemahaman. Ketika seorang peserta didik berupaya memahami sebuah persoalan dengan baik agar bisa menjelaskannya kepada peserta didik lain, maka otomatis ia juga meningkatkan kemampuan pembelajarannya sendiri.

Sedangkan menurut Lie (Pratiwi, D.A \& Sudarmaji, 2017:3) menyatakan bahwa teknik Test-Taking Teams merupakan teknik pembelajaran ini dapat mempermudah peserta didik mencapai tujuan belajar yang spesifik dan dapat berinteraksi sosial pada masyarakat luas. Para anggora kelompok harus 
bekerjasama dalam sebuah tim agar tujuan yang hedak dicapai berhasil dan terselesaikan dengan cepat dan tepat, karena kerjasama dalam tim sangat bergantung pada anggotanya masing-masing. Tidak ada peserta didik yang berhasil sendirian dalam kelompok kecuali semua anggota kelompok bergerak bersamasama bekerja sebagai sebuah tim. Model pembelajaran ini menghendaki peserta didik bekerjasama dalam tim dalam mempersiapkan ujian yang akan diberikan guru dengan cara belajar bersama terlebih dahulu kemudian peserta didik mengerjakan ujian secara individual, setelahnya guru mengatur peserta didik dan memberikan soal kembali dengan sistem dikerjakan dan dipecahkan jawabannya secara bersama-sama.

Berdasarkan hal tersebut dapat disimpulakan bahwa penggunaan model pembelajaran kolaboratif teknik Test-Taking Teams berbantuan multimedia powerpoint, pada tema 8 DaerahTempat Tinggalku kelas IV dapat meningkatkan sikap kerjasama peserta didik, dari penelitian yang telah dilakukan di SD Negeri 02 Bumiayu, peneliti menemukan temuan lain yaitu dengan adanya pemberian kesempatan seluas-luasnya kepada peserta didik seperti untuk menjawab, memberi tanggapan peserta didik akan merasa diberikan sebuah kepercayaan yang harus dijaga. Selain itu pula model pembelajaran kolaboratif teknik Test-Taking Teams berbantuan multimedia powerpoint, dirasa cukup untuk diterapkan disemua pelajaran. Namun demikian, guru dituntut untuk terampil dalam merancang dan melaksanakan kegiatan pembelajaran. Hal ini juga harus disesuaikan dengan kebutuhan peserta didik dan kurikulum yang berlaku.

\section{SIMPULAN}

Berdasarkan hasil penelitian yang telah dilakukan, maka dapat diambil kesimpulan bahwa penerapan model pembelajaran TestTaking Teams berbantuan multimedia powerpoint, dapat meningkatkan sikap kerjasama. Hal ini dapat ditunjukkan pada siklus I diperoleh nilai persentase sebesar $62,1 \%$ dengan kriteria baik, sedangkan pada siklus II keterampilan kerjasama peserta didik mengalami peningkatan nilai persentase sebesar
93,05\% dengan kriteria sangat baik. Peneliti berkolaborasi dengan guru kelas IV SD Negeri 02 Bumiayu agar peserta didik dapat mempunyai keterampilan kerjasama yang sangat baik melalui pembelajaran tema 8 Daerah Tempat Tinggalku.

Setelah melaksanakan penelitian tindakan kelas di SD Negeri 02 Bumiayu peneliti mengajukan saran dalam melaksanakan pembelajaran menggunakan pembelajaran menggunakan pembelajaran model pembelajaran kolaboratif teknik TestTaking Teams berbantuan multimedia powerpoint, yaitu sebagai berikut:Saran bagi guru yaitu guru hendaknya dapat memvariasikan cara mengajarnya agar peserta didik tidak jenuh, dan dapat memanfaatkan penerapan model pembelajaran kolaboratif teknikTest-Taking Teams berbantuan multimedia powerpoin yang telah di terapkan pada penelitian kali ini untuk pembelajaran selanjutnya agar terciptanya suasana belajar yang variatif dan meningkatkan kreatifitas guru dalam mengajar di kelas sehingga peserta didik tertarik dengan materi sehingga dapat menyerap materi dengan baik, mendegarkan guru secara fokus dan prestasi belajar peserta didik meningkat.

\section{DAFTAR PUSTAKA}

Barkley, E.E, K. Patricia Cross \& Claire Howell Major. (2016). Collaborative Learning Techniques: Teknik-Teknik Pembelajaran Kolaboratif. Bandung: Nusa Media.

Chandra, R. (2015). Collaborative Learning for Educational Achievement. Journal of Research \& Method in Education. 5(2): 1-4.

Isjoni \& Ismail, M.A. (2008). Model-model Pembelajaran Mutakhir. Yogyakarta:PustakaPelajar.

Johnson, E.B. (2011). Contextual Teaching and Learning, Menjadikan Kegiatan BelajarMengajar Mengasyikkan dan Bermakna. Bandung: Kaifa.

Maharani, Y.S. (2015) Efektivitas Multimedia Pembelajaran Interaktif Berbasis Kurikulum 2013. IJCETS. 3 (1): 3140. 
Mujtahidin. (2017). Civic Education di Sekolah. Surabaya: Pustaka Radja.

Noryanti, H. (2014). Efektifitas Media Power Point pada Pembelajaran Bidang Studi Bahasa Indonesia di SDN Ngelang 02 Kecamatan Maospati Kabupaten Magetan Tahun 2014/2015. Jurnal Ilmiah Pendididkan. 2(2): 106-113.

Nurwati, E, Dwi Yulianto \& Hadi Susanto. (2012). Peningkatan kerjasama siswa smp melalui penerapan Pembelajaran kooperatif pendekatan think pair share. Unnes Physics Education Journal. 1(1): 1-7.

Pratiwi, D.A \& Sudarmaji. (2017). Keefektifan Penggunaan Teknik Test-Taking Teams Pada Pembelajaran Keterampilan Membaca Bahasa Jerman di SMA Negeri 1 Grabag Magelang. Jurnal Pendidikan Bahasa Jerman. 1(12): 1-12.

Rusman. (2014). Model-Model Pembelajaran: Mengembangkan Profesional Guru. Jakarta: Raja Grafindo Persada.

Sagar, Pratibha, \& N.N. Pandey. (2014). The Effect of Powerpoint Presentations on Academic Achievement of B.Ed. Teacher Trainees. The Effect Of Powerpoint An International Journal of Education. 4(2): 76-85.

Slameto. (2010).Belajar dan Faktor-faktor yang Mempengaruhinya. Jakarta: Rineka Cipta.

Soekanto, S. (2014). Sosiologi Suatu Pengantar. Jakarta: Raja Grafindo Persada.

Utomo, B.T. (2011). Penerapan Pembelajaran Kolaboratif Dengan Asesmen Teman Sejawat Pada Mata Pelajaran Matematika SMP. JP3. 1(1): 52-61. 